Article

\title{
Spiroketones and a Biphenyl Analog from Stems and Leaves of Larrea nitida and Their Inhibitory Activity against IL-6 Production
}

\author{
Jongmin Ahn ${ }^{1, \dagger}$, Yihua Pei ${ }^{2,+}{ }^{,}$Hee-Sung Chae ${ }^{2}$, Seong-Hwan Kim ${ }^{1}$, Young-Mi Kim ${ }^{2}$, \\ Young Hee Choi ${ }^{2}$, Joongku Lee ${ }^{3}$, Minsun Chang ${ }^{4}$, Yun Seon Song ${ }^{5}$, Roberto Rodriguez ${ }^{6}$, \\ Dong-Chan $\mathrm{Oh}^{1}$, Jinwoong Kim ${ }^{1}$, Sangho Choi ${ }^{7}$, Sang Hoon Joo ${ }^{8}$ and Young-Won Chin ${ }^{2, *}$ \\ 1 College of Pharmacy and Research Institute of Pharmaceutical Sciences, Seoul National University, \\ Seoul 08826, Korea; jm212224@snu.ac.kr (J.A.); yanberk@hanmail.net (S.-H.K.); \\ dongchanoh@snu.ac.kr (D.-C.O.); jwkim@snu.ac.kr (J.K.) \\ 2 College of Pharmacy and Integrated Research Institute for Drug Development, Dongguk University-Seoul, \\ Gyeonggi-do 10326, Korea; yeahhwa@gmail.com (Y.P.); chaeheesung83@gmail.com (H.-S.C.); \\ 0210121@hanmail.net (Y.-M.K.); choiyh@dongguk.edu (Y.H.C.) \\ 3 Department of Environment and Forest Resources, College of Agriculture and Life Sciences, Chungnam \\ National University, Daejeon 34134, Korea; joongku@cnu.ac.kr \\ 4 Department of Biological Sciences, College of Science, Sookmyung Women's University, Seoul 04310, Korea; \\ minsunchang@sookmyung.ac.kr \\ 5 College of Pharmacy, Sookmyung Women's University, Seoul 04310, Korea; yssong@sookmyung.ac.kr \\ 6 Department of Botany, University of Concepcion, Casilla 160C, Concepcion 4080871, Chile; rrodrigu@udec.cl \\ 7 International Biological Material Research Center, KRIBB, Daejeon 34141, Korea; decoy0@kribb.re.kr \\ 8 College of Pharmacy, Daegu Catholic University, Gyeongbuk 38430, Korea; sjoo@cu.ac.kr \\ * Correspondence: f2744@dongguk.edu; Tel.: +82-31-961-5218 \\ + These authors contributed equally to this work.
}

Received: 17 January 2018; Accepted: 30 January 2018; Published: 31 January 2018

\begin{abstract}
Bioactivity-guided fractionation for the stems of leaves of Larrea nitida Cav., using interleukin-6 (IL-6) inhibitory assay in human mast cells (HMC-1), led to the isolation of three new compounds with an unprecedented skeleton in nature (1-3) and three known compounds (4-6). Their structures were elucidated through extensive spectroscopic analysis. The three new compounds were elucidated as two new spiroketones, nitidaones A (1), and B (2) and one new biphenyl analog, nitidaol (3). The known compounds were identified as nordihydroguaiaretic acid (4), $7,3^{\prime}, 4^{\prime}$-tri-O-methylquercetin (5) and ayanin (6). All the isolates were tested for their inhibitory activity against IL-6 production in HMC-1 cells. Of them, compounds 1, 3-6 showed potent anti-inflammatory activity, with $\mathrm{IC}_{50}$ values of $12.8,17.5,14.9,22.9$, and $17.8 \mu \mathrm{M}$, respectively.
\end{abstract}

Keywords: Larrea nitida; spiroketones; biphenyl analog; HMC-1; IL-6

\section{Introduction}

The genus Larrea (Zygophyllaceae) has been used for ethnobotanical purposes by the native peoples of northwest, central, and southeast Argentina. This genus comprises five species seen in North and South America: L. ameghinoi Speg., L. nitida Cav., L. divaricata Cav., L. mexicana Moric., and L. tridentata (DC.) Coville [1,2]. Phytochemical studies on the genus Larrea reported the occurrence of flavonoids, lignans, naphthoquinones, saponins, and tannins [3,4]. These plants have been used for the treatment of cancer, inflammation, and menstrual pains [5-7]. Previous phytochemical investigations on L. nitida have reported the presence of flavonoids and lignans $[8,9]$. The biological activities of its extracts or individual ingredients included antifungal activity associated with Argentinean Andean propolis, antioxidant 
activity, and estrogenic activity [8-10]. As a part of our search for IL-6 production inhibitors from higher plants [11-13], L. nitida was selected for further isolation work due to IL-6 production inhibitory activity in the initial screening. Herein, the structural elucidation of three new compounds along with three known compounds and their IL-6 production inhibitory activity are described.

\section{Results and Discussion}

Air-dried stems and leaves of L. nitida (52 g) were extracted with $\mathrm{MeOH}$, and the extract was subjected to bioactivity-guided isolation using diverse chromatography to afford two new spiroketones $(\mathbf{1}, \mathbf{2})$, one new biphenyl analog (3), and three known compounds. The known compounds were identified as nordihydroguaiaretic acid [14] (4), 7,3', 4' -tri-O-methylquercetin [15] (5), and ayanin [16] (6).

Compound 1 was obtained as an amorphous solid, and its molecular formula was deduced as $\mathrm{C}_{21} \mathrm{H}_{26} \mathrm{O}_{4}$ by the protonated ion peak $[\mathrm{M}+\mathrm{H}]^{+}$at $m / z 343.1918$ (calcd. for $\mathrm{C}_{21} \mathrm{H}_{27} \mathrm{O}_{4}, m / z$ 343.1909). The ${ }^{1} \mathrm{H}$ NMR disclosed the presence of a para-substituted benzene ring at $\delta_{\mathrm{H}} 7.28(2 \mathrm{H}, \mathrm{d}, J=9.0 \mathrm{~Hz}$, $\left.\mathrm{H}-2^{\prime}, 6^{\prime}\right)$, and $6.89\left(2 \mathrm{H}, \mathrm{d}, J=9.0 \mathrm{~Hz}, \mathrm{H}-3^{\prime}, 5^{\prime}\right)$, four olefinic protons at $\delta_{\mathrm{H}} 7.19(1 \mathrm{H}, \mathrm{dd}, J=10.0,3.0 \mathrm{~Hz}$, H-3), $7.10(1 \mathrm{H}, \mathrm{dd}, J=10.0,3.0 \mathrm{~Hz}, \mathrm{H}-5), 6.32(1 \mathrm{H}, \mathrm{dd}, J=10.0,1.9 \mathrm{~Hz}, \mathrm{H}-6)$ and $6.29(1 \mathrm{H}, \mathrm{dd}, J=10.0$, $1.9 \mathrm{~Hz}, \mathrm{H}-2)$, an acetyl group at $\delta_{\mathrm{H}} 2.00\left(3 \mathrm{H}, \mathrm{s}, \mathrm{OCOCH}_{3}\right)$, and a methoxy group at $\delta_{\mathrm{H}} 3.76(3 \mathrm{H}, \mathrm{s}$, $\left.\mathrm{OCH}_{3}\right)($ Table 1).

Table 1. The ${ }^{1} \mathrm{H}$ and ${ }^{13} \mathrm{C}$ NMR data of compounds $\mathbf{1}$ and 2 in methanol- $d_{4}$.

\begin{tabular}{|c|c|c|c|c|c|c|}
\hline \multirow[b]{2}{*}{ Position } & \multicolumn{3}{|r|}{ Nitidaone A (1) ${ }^{\text {a }}$} & \multicolumn{3}{|r|}{ Nitidaone B (2) ${ }^{a}$} \\
\hline & $\delta_{C}$ & Type & $\delta_{H}$ & $\delta_{C}$ & Type & $\delta_{\mathrm{H}}(J$ in $\mathrm{Hz})$ \\
\hline 1 & 188.6 & $\mathrm{C}$ & & 202.0 & $\mathrm{C}$ & \\
\hline 2 & 128.5 & $\mathrm{CH}$ & 6.29, dd $(10.0,1.9)$ & 129.3 & $\mathrm{CH}$ & $6.06, \mathrm{~d}(10.3)$ \\
\hline 3 & 158.4 & $\mathrm{CH}$ & 7.19, dd $(10.0,3.0)$ & 159.8 & $\mathrm{CH}$ & 7.38, dd $(10.3,1.5)$ \\
\hline 4 & 50.5 & $\mathrm{C}$ & & 44.7 & $\mathrm{C}$ & \\
\hline 5 & 157.9 & $\mathrm{CH}$ & 7.10, dd $(10.0,3.0)$ & 36.3 & $\mathrm{CH}$ & 2.29-2.40, overlap; $2.14-2.24$, overlap \\
\hline 6 & 129.2 & $\mathrm{CH}$ & $6.32, \mathrm{dd}(10.0,1.9)$ & 35.6 & $\mathrm{CH}$ & 2.29-2.40, overlap; $2.14-2.24$, overlap \\
\hline 7 & 43.2 & $\mathrm{CH}_{2}$ & $2.29, \mathrm{dd}(13.9,2.4) ; 1.95, \mathrm{dd}(13.9,7.6)$ & 46.7 & $\mathrm{CH}_{2}$ & 1.94, d (11.7); 1.61-1.67, overlap \\
\hline 8 & 32.7 & $\mathrm{CH}$ & $1.45, \mathrm{~m}$ & 31.9 & $\mathrm{CH}$ & $1.62-1.68$, overlap \\
\hline 9 & 39.8 & $\mathrm{CH}$ & $1.77, \mathrm{~m}$ & 40.1 & $\mathrm{CH}$ & 1.63-1.69, overlap \\
\hline 10 & 68.1 & $\mathrm{CH}_{2}$ & 4.03, dd $(11.1,6.9) ; 3.85$, dd $(11.1,6.8)$ & 68.2 & $\mathrm{CH}_{2}$ & $3.90, \mathrm{dd}(11.0,6.6) ; 3.78, \mathrm{dd}(11.0,6.7)$ \\
\hline 11 & 19.8 & $\mathrm{CH}_{3}$ & $0.93, \mathrm{~d}(7.0)$ & 19.2 & $\mathrm{CH}_{3}$ & $0.71, \mathrm{~d}(6.4)$ \\
\hline 12 & 13.9 & $\mathrm{CH}_{3}$ & $0.89, \mathrm{~d}(7.0)$ & 13.7 & $\mathrm{CH}_{3}$ & $0.83, \mathrm{~d}(6.9)$ \\
\hline $1^{\prime}$ & 133.4 & C & & 137.0 & C & \\
\hline $2^{\prime}, 6^{\prime}$ & 129.0 & $\mathrm{CH}$ & $7.28, \mathrm{~d}(9.0)$ & 129.3 & $\mathrm{CH}$ & $7.29, \mathrm{~d}(8.9)$ \\
\hline $3^{\prime}, 5^{\prime}$ & 115.5 & $\mathrm{CH}$ & $6.89, \mathrm{~d}(9.0)$ & 115.1 & $\mathrm{CH}$ & $6.90, \mathrm{~d}(8.9)$ \\
\hline $4^{\prime}$ & 160.6 & C & & 160.0 & C & \\
\hline $4^{\prime}-\mathrm{OCH}_{3}$ & 55.9 & $\mathrm{CH}_{3}$ & $3.76, \mathrm{~s}$ & 55.8 & $\mathrm{CH}_{3}$ & $3.78, \mathrm{~s}$ \\
\hline $\mathrm{COCH}_{3}$ & 21.0 & $\mathrm{CH}_{3}$ & $2.00, \mathrm{~s}$ & 21.0 & $\mathrm{CH}_{3}$ & $1.98, \mathrm{~s}$ \\
\hline $\mathrm{O} \overline{\mathrm{CO}}$ & 173.1 & C & & 173.0 & C & \\
\hline
\end{tabular}

From the HMBC NMR spectrum, the correlations between both $\mathrm{H}-3$ and $\mathrm{H}-5$ and the carbonyl carbon at $\delta c 188.6(\mathrm{C}-1)$ and between both H-2 and H-6 and the quaternary carbon at $\delta c 50.5(\mathrm{C}-4)$ suggested a quinoid-type skeleton. The 4-methoxyphenyl group was suggested by the HMBC correlations between one quaternary aromatic carbon at $\delta \mathrm{c} 133.4\left(\mathrm{C}-1^{\prime}\right)$ and $\mathrm{H}-3^{\prime}, 5^{\prime}$ and between another quaternary aromatic carbon at $\delta c 160.6\left(\mathrm{C}-4^{\prime}\right)$ and both methoxy protons $\left(\delta_{\mathrm{H}} 3.76\right)$ and two aromatic protons $\left(\mathrm{H}-2^{\prime}, 6^{\prime}\right)$. A 2,3-dimethylbutoxy group was confirmed by the ${ }^{1} \mathrm{H}$ and COSY NMR signals at $\delta_{\mathrm{H}} 4.03(1 \mathrm{H}, \mathrm{dd}, J=11.1,6.9 \mathrm{~Hz}, \mathrm{H}-10 \mathrm{a}), 3.85(1 \mathrm{H}, \mathrm{dd}, J=11.1,6.8 \mathrm{~Hz}, \mathrm{H}-10 \mathrm{~b}), 2.29(1 \mathrm{H}$, $\mathrm{dd}, J=13.9,2.4 \mathrm{~Hz}, \mathrm{H}-7 \mathrm{a}), 1.95(1 \mathrm{H}, \mathrm{dd}, J=13.9,7.6 \mathrm{~Hz}, \mathrm{H}-7 \mathrm{~b}), 1.77$ (1H, m, H-9), 1.45 (1H, m, H-8), $0.93(3 \mathrm{H}, \mathrm{d}, J=7.0 \mathrm{~Hz}, \mathrm{H}-11)$ and $0.89(3 \mathrm{H}, \mathrm{d}, J=7.0 \mathrm{~Hz}, \mathrm{H}-12)$. The COSY NMR spectrum showed correlations between $\mathrm{H}-11$ and $\mathrm{H}-8$, between $\mathrm{H}-12$ and $\mathrm{H}-9$ and sequential correlations from $\mathrm{H}-7$ to $\mathrm{H}-10$.

The link between these groups was confirmed by the HMBC correlations (Figure 1). The correlations between 4-methoxyphenyl protons $\left(\mathrm{H}-2^{\prime}, 6^{\prime}\right)$ and $\mathrm{C}-4\left(\delta_{\mathrm{C}} 50.5\right)$ and between protons $(\mathrm{H}-7 \mathrm{a}$ and $7 \mathrm{~b})$ on a 2,3-dimethylbutoxy group and both C-4 and C- $1^{\prime}$ enabled us to put these groups together via a spiral 
carbon at C-4, as depicted in Figure 1 . The acetyl group was affixed to $\mathrm{C}-10$ from the observed correlations between $\delta_{C} 173.1$ and both $\mathrm{H}-10$ and methyl protons $\left(\delta_{\mathrm{H}} 2.00\right)$. Therefore, the structure of compound 1 was determined to be 4-(1-(4-methoxyphenyl)-4-oxocyclohexa-2,5-dienyl)-2,3-dimethylbutyl acetate, named nitidaone A.

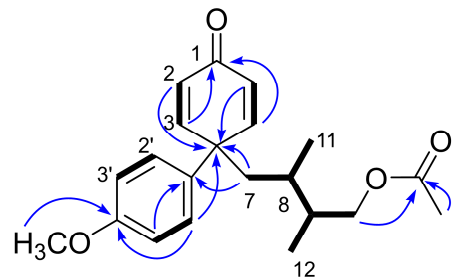

1

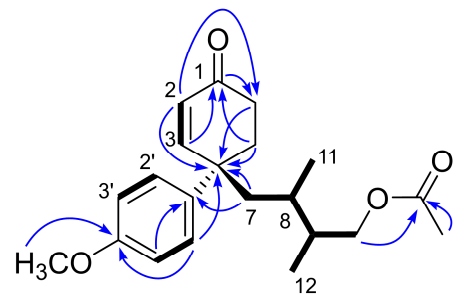

2

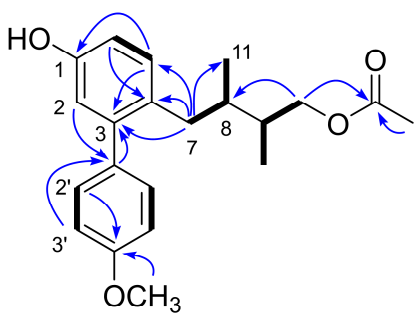

3

Figure 1. Key ${ }^{1} \mathrm{H},{ }^{1} \mathrm{H}-\mathrm{COSY}$ (bold line) and HMBC (blue arrow) correlations of compounds 1-3.

A protonated molecular ion $[\mathrm{M}+\mathrm{H}]^{+}$at $m / z 345.2069$ (calcd. for $\mathrm{C}_{21} \mathrm{H}_{29} \mathrm{O}_{4}, 345.2066$ ) of compound 2 suggested its molecular formula as $\mathrm{C}_{21} \mathrm{H}_{28} \mathrm{O}_{4}$. The ${ }^{1} \mathrm{H}$ NMR data of 2 (Table 1) were similar to those of 1 except for the absence of two olefinic protons. Instead of olefinic protons, methylene signals at $\delta_{\mathrm{H}}$ 2.40-2.29 (2H) and $\delta_{\mathrm{H}} 2.24-2.14(2 \mathrm{H})$ were observed in the spectrum of 2, assignable to $\mathrm{H}-5$ and $\mathrm{H}-6$. Furthermore, the HMBC correlations of H-7 with C-4 $\left(\delta_{C} 44.7\right)$ and C- $1^{\prime}\left(\delta_{C} 137.0\right)$ and H-2',6 $6^{\prime}$ with C-4 confirmed its spiral skeleton (Figure 1). Taken together with all data, this compound was elucidated as 4-(1-(4-methoxyphenyl)-4-oxocyclohex-2-enyl)-2,3-dimethylbutyl acetate, named nitidaone B.

It has been reported that 2-cyclohexenones empirically give a negative Cotton effect $\left(n \rightarrow \pi^{*}\right)$ in the $340 \mathrm{~nm}$ region if the ring has a half-chair conformation with a pseudo-axial disposition of an aryl group (Figure 2a) [17]. From a negative Cotton effect at $339 \mathrm{~nm}$ in the CD spectrum of 2, it was affirmed that the cyclohexenone ring of this compound prefers the half-chair conformation with a pseudo-axial aromatic group at room temperature (Figure $2 b$ ). Therefore, the absolute configuration of C-4 was established to be $R$.

The exciton splitting theory supported its $R$ configuration. From the UV and CD spectrum, the negative exciton-split Cotton effect at $220 \mathrm{~nm}$ was observed due to the $\pi \rightarrow \pi^{*}$ intramolecular chargetransfer transition of a 4-methoxyphenyl chromophore and a 2-cyclohexenone chromophore [18,19]. The negative exciton-split Cotton effect indicated that the two electric transition moments of these chromophores were rotated in a counterclockwise direction, as shown in Figure 2c.

The ${ }^{1} \mathrm{H}$ and COSY NMR data of compound 3 displayed an 1,2,4-substituted benzene ring at $\delta_{\mathrm{H}} 7.01(1 \mathrm{H}, \mathrm{d}, J=8.3 \mathrm{~Hz}, \mathrm{H}-5), 6.67(1 \mathrm{H}, \mathrm{dd}, J=8.3,2.7 \mathrm{~Hz}, \mathrm{H}-6)$ and $6.58(1 \mathrm{H}, \mathrm{d}, J=2.7 \mathrm{~Hz}, \mathrm{H}-2)$, an 1,4-disubstituted benzene ring at $\delta_{\mathrm{H}} 7.16\left(2 \mathrm{H}, \mathrm{d}, J=8.8 \mathrm{~Hz}, \mathrm{H}-2^{\prime}, 6^{\prime}\right)$ and $6.92(2 \mathrm{H}, \mathrm{d}, J=8.8 \mathrm{~Hz}$, $\left.\mathrm{H}-3^{\prime}, 5^{\prime}\right)$ and a 2,3-dimethylbutoxy group at $\delta_{\mathrm{H}} 3.66(2 \mathrm{H}, \mathrm{m}, \mathrm{H}-10), 2.78(1 \mathrm{H}, \mathrm{dd}, J=13.6,4.9 \mathrm{~Hz}, \mathrm{H}-7 \mathrm{a})$, $2.19(1 \mathrm{H}, \mathrm{dd}, J=13.6,9.7 \mathrm{~Hz}, \mathrm{H}-7 \mathrm{~b}), 1.55(1 \mathrm{H}, \mathrm{m}, \mathrm{H}-9), 1.47(1 \mathrm{H}, \mathrm{m}, \mathrm{H}-8), 0.74$ (3H, d, J = 6.9 Hz, H-12), and $0.65(3 \mathrm{H}, \mathrm{d}, J=6.9 \mathrm{~Hz}, \mathrm{H}-11)$. Also, a methoxy group at $\delta_{\mathrm{H}} 3.82\left(3 \mathrm{H}, \mathrm{s}, \mathrm{OCH}_{3}\right)$ and an acetyl group at $\delta_{\mathrm{H}} 1.95\left(3 \mathrm{H}, \mathrm{s}, \mathrm{OCOCH}_{3}\right)$ was observed (Table 2).

From the HMBC NMR spectrum, the correlations between $\mathrm{H}-2$ and two quaternary aromatic carbons at $\delta c 156.4$ (C-1) and 144.5 (C-3) and between H-6 and another quaternary carbon at $\delta c$ 131.1 (C-4) confirmed a 1-hydroxy-3,4-disubstituted benzene ring. The 4-methoxyphenyl group was suggested by the HMBC correlations between one quaternary aromatic carbon at $\delta \mathrm{c} 136.0\left(\mathrm{C}-1^{\prime}\right)$ and $\mathrm{H}-3^{\prime}, 5^{\prime}$ and between the other quaternary aromatic carbon at $\delta \mathrm{c} 160.2\left(\mathrm{C}-4^{\prime}\right)$ and both methoxy protons $\left(\delta_{\mathrm{H}} 3.82\right)$ and two aromatic protons $\left(\mathrm{H}-2^{\prime}, 6^{\prime}\right)$. A 2,3-dimethylbutoxy group was assigned by the sequential COSY correlations from $\mathrm{H}-7$ to $\mathrm{H}-11$ and from $\mathrm{H}-10$ to $\mathrm{H}-12$ and the HMBC correlation between $\mathrm{H}-10$ and $\mathrm{C}-8\left(\delta_{\mathrm{C}} 37.8\right)$. The link of these substructures was confirmed by the observed HMBC correlations (Figure 1). The HMBC signals between H-2 and C-1' and between $\mathrm{H}-2^{\prime}, 6^{\prime}$ and 
C-3 indicated that C-3 was connected to C-1'. The HMBC correlations between H-7 and C-3, C-4 and C-5 enabled to connect a 2,3-dimethylbutoxy group to C-4 position. The correlations of $\delta_{\mathrm{C}} 173.1$ with both $\mathrm{H}-10$ and a methyl proton $\left(\delta_{\mathrm{H}}\right.$ 1.95) made it possible to link the acetyl group to C-10 position through an ester linkage (Figure 1). Therefore, the structure of this compound was determined to be 4-(5-hydroxy-4'-methoxybiphenyl-2-yl)-2,3-dimethylbutyl acetate, named nitidaol, as shown in Figure 1.

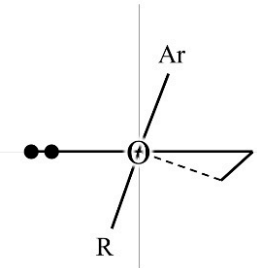

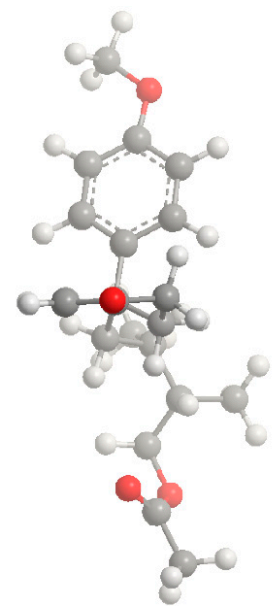

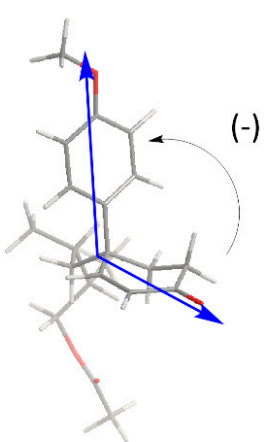

Figure 2. 2-Cyclohexenone conformations: (a) Half-chair conformation with a pseudo-axial aromatic group giving a negative Cotton effect at $340 \mathrm{~nm}$; (b) half-chair conformation with a pseudo-axial aromatic group of (4R)-2; (c) negative exciton-split Cotton effect of (4R)-2.

Table 2. The ${ }^{1} \mathrm{H}$ and ${ }^{13} \mathrm{C}$ NMR data of compound 3 in methanol- $d_{4}$

\begin{tabular}{|c|c|c|c|}
\hline \multirow[b]{2}{*}{ Position } & \multicolumn{3}{|c|}{ Nitidaol (3) ${ }^{a}$} \\
\hline & $\delta_{C}$ & Type & $\delta_{H}(J$ in $\mathrm{Hz})$ \\
\hline 1 & 156.4 & C & \\
\hline 2 & 118.2 & $\mathrm{CH}$ & $6.58, \mathrm{~d}(2.7)$ \\
\hline 3 & 144.5 & $\mathrm{C}$ & \\
\hline 4 & 131.1 & C & \\
\hline 5 & 132.6 & $\mathrm{CH}$ & $7.01, \mathrm{~d}(8.3)$ \\
\hline 6 & 114.9 & $\mathrm{CH}$ & $6.67, \mathrm{dd}(8.3,2.7)$ \\
\hline 7 & 36.8 & $\mathrm{CH}_{2}$ & $2.78 \mathrm{dd}(13.6,4.9)$ \\
\hline & & & 2.19, dd $(13.6,9.7)$ \\
\hline 8 & 37.8 & $\mathrm{CH}$ & $1.47, \mathrm{~m}$ \\
\hline 9 & 38.2 & $\mathrm{CH}$ & $1.55, \mathrm{~m}$ \\
\hline 10 & 68.7 & $\mathrm{CH}_{2}$ & $3.66, \mathrm{~m}$ \\
\hline 11 & 16.8 & $\mathrm{CH}_{3}$ & $0.65, d(6.9)$ \\
\hline 12 & 14.1 & $\mathrm{CH}_{3}$ & $0.74, \mathrm{~d}(6.9)$ \\
\hline $1^{\prime}$ & 136.0 & $\mathrm{C}$ & \\
\hline $2^{\prime}, 6^{\prime}$ & 131.4 & $\mathrm{CH}$ & $7.16, \mathrm{~d}(8.8)$ \\
\hline $3^{\prime}, 5^{\prime}$ & 114.7 & $\mathrm{CH}$ & $6.92, \mathrm{~d}(8.8)$ \\
\hline $4^{\prime}$ & 160.2 & $\mathrm{C}$ & \\
\hline $4^{\prime}-\mathrm{OCH}_{3}$ & 55.8 & $\mathrm{CH}_{3}$ & $3.82, \mathrm{~s}$ \\
\hline $\mathrm{COCH}_{3}$ & 21.0 & $\mathrm{CH}_{3}$ & $1.95, \mathrm{~s}$ \\
\hline $\mathrm{OC} \underline{\mathrm{CO}}$ & 173.1 & $\mathrm{C}$ & \\
\hline
\end{tabular}

${ }^{\mathrm{a} 1} \mathrm{H}$ and ${ }^{13} \mathrm{C}$ NMR were measured at 400 and $100 \mathrm{MHz}$, respectively.

All the isolates were tested against IL-6 production inhibitory activity in the HMC-1 cells induced by PMA + A23187. Of these, compounds 1 and 3-6 were found to be active with $\mathrm{IC}_{50} 12.8,17.5,14.9$, 
22.9 and $17.8 \mu \mathrm{M}$, respectively (positive control, $\mathrm{IC}_{50}$ of montelukast, $8.7 \mu \mathrm{M}$ ), while compound 2 seemed inactive $\left(\mathrm{IC}_{50}>25 \mu \mathrm{M}\right)$.

\section{Materials and Methods}

\subsection{General Experimental Procedures}

Optical rotation was measured with a Jasco P2000 polarimeter (Jasco Corporation, Tokyo, Japan), and FT-IR spectra using a Jasco FT/IR-4200 (Jasco corporation, Japan). ECD and UV spectra were recorded with an Applied Photophysics Chirascan-plus CD spectrometer. ${ }^{1} \mathrm{H},{ }^{13} \mathrm{C}$ and $2 \mathrm{D}$ NMR spectra were obtained on a Varian 400 (Varian, Palo Alto, CA, USA)-400MHz. Waters Xevo G2 Q-TOF, (Waters, Milford, MA, USA) spectra were measured on a Q-TOF mass spectrometer. Semi-preparative high-performance liquid chromatography (HPLC) was performed on a Gilson 321 pump, Gilson 172 Diode Array Detector (Gilson, Middleton, WI, USA). YMC-pack Ph, $250 \times 20$ mm (YMC, Tokyo, Japan) and Luna $5 \mathrm{u}$ C18 column $250 \times 10 \mathrm{~nm}$ (Phenomenex) as HPLC columns were used. MPLC was run on Isolera One (Biotage, Cardiff, UK). Solvents for HPLC were acetonitrile (MeCN) (HPLC grade) and methanol (HPLC grade), purchased from SK Chemical (Seoul, Korea). Water was purified using a MIlli-Q system (Millipore, Bedford, MA, USA). Column chromatography was performed on C-18 RP silica gel (Cosmosil, Kyoto, Japan) and Sephadex LH-20 (GE Healthcare, Stockholm, Sweden). TLC analysis was run on silica gel $60 \mathrm{~F}_{254}$ plates (Marck, Darmstadt, Germany). The spots were visualized by spraying with $10 \%$ aqueous $\mathrm{H}_{2} \mathrm{SO}_{4}$.

\subsection{Plant Material}

The stems and leaves of L. nitida Cav. were collected at Jarilla, Chile in 2007 and identified by Dr. Joongku Lee, Korea Research Institute of Bioscience and Biotechnology. A voucher specimen (access number FBM026-052) was deposited in the herbarium of the Korea Research Institute of Bioscience and Biotechnology, Daejeon, Republic of Korea.

\subsection{Extraction and Isolation}

Air-dried stems and leaves of L. nitida (52 g) were pulverized and extracted with $\mathrm{MeOH}$ to yield the crude extract (14 g). A portion of this extract (12 g) was subjected to a reverse-phase silica gel column chromatography eluting with a gradient of $\mathrm{H}_{2} \mathrm{O}-\mathrm{MeOH}$ (90:10-0:100) to give 17 sub-fractions (LN01-17). Of these sub-fractions, LN 8 and 11 were found to inhibit IL-6 production (over 50\% inhibition at $20 \mu \mathrm{g} / \mathrm{mL}$ ) in HMC-1 cells stimulated by PMA + A23187 (Figure S6). LC8 (1 g) was fractionated into $14 \mathrm{sub}$-fractions using a reversed phase silica gel column chromatography with a gradient mixture of $\mathrm{MeOH}-\mathrm{H}_{2} \mathrm{O}$ (25:75 to 100:0).

Further HPLC separation for LC8-9 (Phenomenex Luna C18, MeCN 40\%) yielded nordihydroguiaretic acid $\left(6.8 \mathrm{mg}, t_{\mathrm{R}} 38.04 \mathrm{~min}\right)$. LN11 (1.2 g) was further fractionated by medium-pressure liquid chromatography (Biotage), eluted with a gradient mixture of $\mathrm{MeOH}-\mathrm{H}_{2} \mathrm{O}=40: 60-100: 0$ ), and then pooled into $16 \mathrm{sub}$-fractions (LN11-1 to LN11-16). Compound 1 (14.5 mg, $t_{\mathrm{R}} 84.73 \mathrm{~min}$ ) was separated from LN11-10 (106 mg) using HPLC separation (Phenomenex Luna C18 $250 \times 10,5 \mu \mathrm{m}, 2 \mathrm{~mL} / \mathrm{min}, 45 \% \mathrm{MeCN}$ in $\mathrm{H}_{2} \mathrm{O}$ ). LN11-12 (249 mg) was separated using an HPLC column (Phenomenex Luna C18 250 $\times 10,5 \mu \mathrm{m}$, $2 \mathrm{~mL} / \mathrm{min}$ ) eluted with a gradient solvent system [45\% in $\mathrm{H} 2 \mathrm{O}$ (1 to $56 \mathrm{~min}$ ), 55\% in $\mathrm{H} 2 \mathrm{O}$ (56.01 to $71 \mathrm{~min}$ ), $80 \%$ in $\mathrm{H} 2 \mathrm{O}$ (71.01 to $78 \mathrm{~min}), 100 \% \mathrm{MeCN}$ (78.01 to $85 \mathrm{~min})]$ to yield $3^{\prime}, 4^{\prime}, 7$-trimethylquercetin (1.7 $\mathrm{mg}, \mathrm{tR}$ $54.15 \mathrm{~min}$ ), 3,7,3'-trimethylquercetin ( $1.6 \mathrm{mg}, \mathrm{tR}=55.98 \mathrm{~min}$ ), and 2 (5.1 $\mathrm{mg}$, tR $78.00 \mathrm{~min}$ ). From LN11-13 $(118 \mathrm{mg})$, compound $3\left(5.0 \mathrm{mg}, t_{\mathrm{R}}=28.58 \mathrm{~min}\right)$ was purified using sequentially connected two columns [Luna C18 $(250 \times 10,5 \mu \mathrm{m})+$ YMC-packed ODS-AM $(150 \times 10,2 \mathrm{~mL} / \mathrm{min}, 5 \mu \mathrm{m})$ ] with isocratic elution of $70 \% \mathrm{MeCN}$ in $\mathrm{H}_{2} \mathrm{O}$.

Nitidaone $A(\mathbf{1})$ : white amorphous solid; $[\alpha]_{D}^{20}-42.1^{\circ}\left(\right.$ c 0.5, MeOH); UV (MeOH) $\lambda_{\max }(\log \varepsilon) 256$ (3.60), 272 (3.41) nm; ${ }^{1} \mathrm{H}$ and ${ }^{13} \mathrm{C}$ NMR data, see Table 1; HRESIMS $m / z 343.1918[\mathrm{M}+\mathrm{H}]^{+}$(calcd. for $\left.\mathrm{C}_{21} \mathrm{H}_{26} \mathrm{O}_{4}, 343.1909\right)$. 
Nitidaone B (2): white amorphous solid; $[\alpha]_{D}^{20}-53.9^{\circ}(c 0.1, \mathrm{MeOH}) ; \mathrm{UV}(\mathrm{MeOH}) \lambda_{\max }(\log \varepsilon) 208$ (3.79), $212(3.82) \mathrm{nm} ; \mathrm{CD}(\mathrm{MeOH}) \lambda_{\max }\left(\Delta_{\varepsilon}\right) 208(-0.05), 216(0.08), 233(-0.30), 339(-0.04) ;{ }^{1} \mathrm{H}$ and ${ }^{13} \mathrm{C} \mathrm{NMR}$ data, see Table 1; HRESIMS $m / z$ 345.2069 [M+ H] $]^{+}$(calcd. for $\mathrm{C}_{21} \mathrm{H}_{28} \mathrm{O}_{4}, 345.2066$ ).

Nitidaol (3): white amorphous solid; $[\alpha]_{D}^{20}-4.94^{\circ}(c 0.2, \mathrm{MeOH}) ; \mathrm{UV}(\mathrm{MeOH}) \lambda_{\max }(\log \varepsilon) 257$ (3.63), 281 (3.60) nm; ${ }^{1} \mathrm{H}$ and ${ }^{13} \mathrm{C}$ NMR data, see Table 2; HRESIMS $m / z 343.1913[\mathrm{M}+\mathrm{H}]^{+}$(calcd. for $^{2}$ $\left.\mathrm{C}_{21} \mathrm{H}_{26} \mathrm{O}_{4}, 343.1909\right)$.

\subsection{Interleukin-6 Determination}

Cells were seeded at $1 \times 10^{6} / \mathrm{mL}$ per well in 24-well tissue culture plates and pretreated with the indicated concentration of compounds for $30 \mathrm{~min}$ before stimulation by PMA (50 nM) + A23187 $(1 \mu \mathrm{M})$. After $24 \mathrm{~h}$, the supernatant was decanted into a new micro-centrifuge tube, and the amount of interleukin-6 (IL-6) was determined using an enzyme-linked immunosorbent assay (ELISA) kit according to the procedures described by the manufacturer (BD Biosciences, San Jose, CA, USA). All subsequent steps took place at room temperature, and all standards and samples were assayed in duplicate [13].

\section{Conclusions}

Two new spiroketones $(\mathbf{1}, \mathbf{2})$ and one new biphenyl analog $(\mathbf{3})$, together with three known compounds, were isolated from the stems and leaves of L. nitida. Three new compounds (1-3) have unprecedented skeletons in nature. The absolute configuration of C-4 (compound 2) was demonstrated by ECD analysis, but that of C-8 and C-9 (compounds 1-3) could not be identified. All the isolates were tested against IL-6 production inhibitory activity in the HMC-1 cells induced by PMA+A23187. It was found that nitidaone A (1), nitidaol (3), nordihydroguaiaretic acid (4), 7,3', 4' -trimethylquercetin (5), and 3,7,3'-trimethylquercetin (6) remarkably downregulated the PMA+A23187-induced synthesis of interleukin-6 (IL-6) in HMC-1 cells without cytotoxicity.

Supplementary Materials: The supplementary materials are available online.

Acknowledgments: This work was supported by the Procurement and Development of Biological Resources fund (2011-00404) of the Ministry of Education, Science, and Technology of the Korean government, and the National Research Foundation of Korea (NRF), also funded by the Korean government (MSIT) (2017R1D1A1A02018536, S.H. Joo, NRF-2015R1A2A2A01006736, Y.-W. Chin).

Author Contributions: Young-Won Chin conceived and designed the experiments; Yihua Pei, Jongmin Ahn, Young-Mi Kim, Hee-Sung Chae and Joongku Lee performed the experiments; Jongmin Ahn, Young-Won Chin and Jinwoong Kim analyzed the data; Seong-Hwan Kim, Young Hee Choi, Minsun Chang, Yun Seon Song, Roberto Rodriguez, Dong-Chan Oh, Sangho Choi and Sang Hoon Joo contributed reagents/materials/analysis tools; Jongmin Ahn and Young-Won Chin wrote the paper.

Conflicts of Interest: The authors declare no conflict of interest.

\section{References}

1. Lia, V.; Comas, C.I.; Cortés, M.C.; Hunziker, J.H. Isozyme variation in Larrea ameghinoi and Larrea nitida (Zygophyllaceae): Genetic diversity and its bearing on their relationship. Genetica 1999, 106, 197-207. [CrossRef] [PubMed]

2. Lia, V.V.; Confalonieri, V.A.; Comas, C.I.; Hunziker, J.H. Molecular Phylogeny of Larrea and Its Allies (Zygophyllaceae): Reticulate Evolution and the Probable Time of Creosote Bush Arrival to North America. Mol. Phylogenet. Evol. 2001, 21, 309-320. [CrossRef] [PubMed]

3. Hunziker, J.H.; Palacios, R.A.; De Valesi, A.G.; Poggio, L. Species disjunctions in Larrea: Evidence from morphology, cytogenetics, phenolic compounds, and seed albumins. Ann. Mo. Bot. Gard. 1972, 59, 224-233. [CrossRef]

4. Sakakibara, M.; Difeo, D.; Nakatani, N.; Timmermann, B.; Mabry, T.J. Flavonoid methyl ethers on the external leaf surface of Larrea tridentata and L. Divaricata. Phytochemistry 1976, 15, 727-731. [CrossRef]

5. Abou-Gazar, H.; Bedir, E.; Takamatsu, S.; Ferreira, D.; Khan, I.A. Antioxidant lignans from Larrea tridentata. Phytochemistry 2004, 65, 2499-2505. [CrossRef] [PubMed] 
6. Leonforte, J.F. Contact dermatitis from Larrea (creosote bush). J. Am. Acad. Dermatol. 1986, 14, $202-207$. [CrossRef]

7. Agüero, M.B.; Svetaz, L.; Baroni, V.; Lima, B.; Luna, L.; Zacchino, S.; Saavedra, P.; Wunderlin, D.; Feresin, G.E.; Tapia, A. Urban propolis from San Juan province (Argentina): Ethnopharmacological uses and antifungal activity against Candida and dermatophytes. Ind. Crops Prod. 2014, 57, 166-173. [CrossRef]

8. Agüero, M.B.; Svetaz, L.; Sánchez, M.; Luna, L.; Lima, B.; López, M.L.; Zacchino, S.; Palermo, J.; Wunderlin, D.; Feresin, G.E.; et al. Argentinean Andean propolis associated with the medicinal plant Larrea nitida Cav. (Zygophyllaceae). HPLC-MS and GC-MS characterization and antifungal activity. Food Chem. Toxicol. 2011, 49, 1970-1978. [CrossRef] [PubMed]

9. Torres, R.; Urbina, F.; Morales, C.; Modak, B.; Monache, F.D. Antioxidant properties of lignans and rerulic acid from the resinous exudate of Larrea nitida. J. Chil. Chem. Soc. 2003, 48. [CrossRef]

10. Ahn, H.-N.; Jeong, S.-Y.; Bae, G.-U.; Chang, M.; Zhang, D.; Liu, X.; Pei, Y.; Chin, Y.-W.; Lee, J.; Oh, S.-R.; et al. Selective estrogen receptor modulation by Larrea nitida on MCF-7 cell proliferation and immature rat uterus. Biomol. Ther. 2014, 22, 347-354. [CrossRef] [PubMed]

11. Pel, P.; Kim, Y.-M.; Chin, Y.-W. Chemical Constituents with Anti-allergic Activity from the Barks of Cinnamomum cambodianum Collected in Cambodia. Bull. Korean Chem. Soc. 2015, 36, 384-387. [CrossRef]

12. Quan, G.-H.; Chae, H.-S.; Song, H.H.; Ahn, K.-S.; Lee, H.-K.; Kim, Y.-H.; Oh, S.-R.; Chin, Y.-W. Anti-allergic flavones from Arthraxon hispidus. Chem. Pharm. Bull. (Tokyo) 2013, 61, 920-926. [CrossRef] [PubMed]

13. Kim, Y.-M.; Chae, H.-S.; Lee, E.J.; Yang, M.H.; Park, J.H.; Yoon, K.D.; Kim, J.; Ahn, H.C.; Choi, Y.H.; Chin, Y.-W. A Citrus flavonoid, 6-demethoxytangeretin, suppresses production and gene expression of interleukin-6 in Human Mast Cell-1 via anaplastic lymphoma kinase and mitogen-activated protein kinase pathways. Biol. Pharm. Bull. 2014, 37, 871-876. [CrossRef] [PubMed]

14. Yokosuka, A.; Matsuo, Y.; Jitsuno, M.; Adachi, K.; Mimaki, Y. Larrealignans A and B, novel lignan glycosides from the aerial parts of Larrea tridentata. Chem. Pharm. Bull. (Tokyo) 2011, 59, 1467-1470. [CrossRef] [PubMed]

15. Hu, H.; Zhang, X.; Wu, Y. Antitumor activity of stilbenoids and flavonoids isolated from Acanthopanax brachypus. Russ. J. Gen. Chem. 2014, 84, 1434-1441. [CrossRef]

16. Matsuda, H.; Morikawa, T.; Toguchida, I.; Yoshikawa, M. Structural requirements of flavonoids and related compounds for aldose reductase inhibitory activity. Chem. Pharm. Bull. (Tokyo) 2002, 50, 788-795. [CrossRef] [PubMed]

17. Nieuwenhuis, J.J.; Strelow, F.; Strauss, H.F.; Wiechers, A. (4R)-(-)-O-Methyljoubertiamine and Omethyldihydrojoubertiamine, two minor alkaloids from Sceletium subvelutium L. Bolus. J. Chem. Soc. Perkin Trans. 1 1981, 284-286. [CrossRef]

18. Dauben, W.G.; Shaffer, G.W.; Vietmeyer, N.D. Alkyl-substitution effects in the photochemistry of 2-cyclohexenones. J. Org. Chem. 1968, 33, 4060-4069. [CrossRef]

19. Pavia, D.L.; Lampman, G.M.; Kriz, G.S.; Vyvyan, J.R. Introduction to Spectroscopy, 4th ed.; Brooks Cole: Belmont, CA, USA, 2009; pp. 387-408, ISBN-13 978-0-495-11478-9.

Sample Availability: Not available.

(C) 2018 by the authors. Licensee MDPI, Basel, Switzerland. This article is an open access article distributed under the terms and conditions of the Creative Commons Attribution (CC BY) license (http:/ / creativecommons.org/licenses/by/4.0/). 